\title{
Analysis of the preparation and administration of medications in the hospital context based on Lean thinking
}

\author{
Análise do preparo e administração de medicamentos no contexto hospitalar com base no \\ pensamento Lean
}

\section{Análisis de la preparación y administración de medicamentos en el contexto hospitalario con base en el pensamiento Lean}

Diovane Ghignatti da Costa ${ }^{1,2}$ Simone Silveira Pasin ${ }^{2}$

Ana Maria Müller de Magalhães ${ }^{1,2}$ (D) Gisela Maria Schebella Souto de Moura ${ }^{1}$ Caroline Brum Rosso ${ }^{1}$ Tarcisio Abreu Saurin ${ }^{1}$

1. Universidade Federal do Rio Grande do Sul. Porto Alegre, RS, Brasil.

2. Hospital de Clínicas de Porto Alegre. Porto Alegre, RS, Brasil.
Corresponding author:

Diovane Ghignatti da Costa.

E-mail: dgcosta@hcpa.edu.br

Submitted on $12 / 17 / 2017$.

Accepted on 05/25/2018.

DOI: 10.1590/2177-9465-EAN-2017-0402

\begin{abstract}
Objectives: To analyze the current way medications are prepared and administered in the hospital setting and to apply a method to establish priorities for problems detected. Method: This is an exploratory-descriptive case study. The data were collected through observation and focus groups with 13 participants who were part of a health team in a surgical inpatient unit of a public university hospital. The analysis was based on a lean production framework. Results: A value stream map was constructed of the current way drugs are prepared and administered, identifying the clients in the process and their requirements. Forty-five current problems were identified, based on requirements that were not met with eight being prioritized to improve planning. Conclusion: Having prioritized the problems, the planning and implementation of continuous improvements in the medication process were started in order to reduce errors and improve the quality of services.
\end{abstract}

Keywords: Patient Safety; Medication Errors; Quality of Health Care; Organization and Administration; Process Assessment.

\section{Resumo}

Objetivos: Analisar a situação atual do preparo e administração de medicamentos no contexto hospitalar e aplicar método para estabelecer prioridades entre os problemas levantados. Método: Estudo de caso, exploratório-descritivo. A coleta de dados deu-se por meio de observação e dois Grupos Focais com 13 participantes que integravam a equipe de saúde de uma unidade de internação cirúrgica de um hospital público universitário. A análise seguiu o referencial Lean ou produção enxuta. Resultados: Construiu-se o Mapa de Fluxo de Valor do estado atual do preparo e administração de medicamento, identificando-se os clientes do processo e seus requisitos. Entre os 45 problemas vigentes levantados, com base nos requisitos não atendidos, oito foram priorizados com vistas ao planejamento de melhorias. Conclusão: Na medida em que os problemas foram priorizados iniciaram-se o planejamento e implantação de melhorias contínuas no processo de medicação, com vistas a reduzir erros e melhorar a qualidade dos serviços.

Palavras-chave: Segurança do Paciente; Erros de Medicação; Qualidade da Assistência à Saúde; Organização e Administração; Avaliação de Processos.

\section{Resumen}

Objetivos: Analizar la situación actual de la preparación y administración de medicamentos en el contexto hospitalario y aplicar método para establecer prioridades entre los problemas levantados. Método: Estudio de caso, exploratorio-descriptivo. La recolección de datos se dio por medio de observación y dos Grupos Focales con 13 participantes que integran el equipo de salud de una unidad de internación quirúrgica de un hospital público universitario. El análisis siguió el referencial Lean o producción sobria. Resultados: Se constituyó el Mapa de Flujo de Valor del estado actual de la preparación y administración de medicamento, identificando los clientes del proceso y sus requisitos. Se listaron 45 problemas vigentes, con base en los requisitos no atendidos, con vistas a la planificación de mejoras. Conclusión: En la medida en que se dio prioridad a los problemas, se inició la planificación e implantación de mejoras continuada del proceso de medicación, con vistas a reducir errores y a mejorar la calidad de los servicios.

Palabras clave: Seguridad del Paciente; Errores de Medicación; Calidad de la Atención de Salud; Organización y Administración Evaluación de Proceso. 


\section{INTRODUCTION}

In the current scenario of the global health system, there is a constant search for effective and efficient methods and strategies to promote improvements in the quality and safety of the services offered. The need to apply methods to track results and invest in continuous improvements has instigated, valued and integrated different sources of health knowledge. This integration has identified structural, managerial and procedural aspects related to patient care.

Recently, Lean thinking has reached health institutions and its application has provided changes, since the use of its tools, besides reducing wasted time, resources and work, promotes improvements in the quality of services and products, and the satisfaction of patients and staff. ${ }^{1-3}$ Lean thinking is conceptualized as "a management system that aims to improve processes or a set of actions required to accomplish a task", ${ }^{3}$ that is used to "create and produce the maximum value from the customer's point of view while consuming the minimum resources and fully utilizing the knowledge and skills of the people who perform the task". ${ }^{4}$ The principles of the Lean philosophy promote a differentiated view of the system, recovering the purpose of focusing on assistance to meet the needs of the patient. ${ }^{1}$

In the specific setting of hospital institutions, the medication process is considered one of the most critical in patient care as it is the main resource used in the treatment of diseases. ${ }^{5}$ Medication administration is an activity performed mainly by the nursing team, however, it is important to remember it is linked to other areas as part of the entire medication process. ${ }^{6}$

Currently, there is a debate about the safety of the medication process. This may compromise the quality of patient care due to subjective interpretation of the prescription, ${ }^{7}$ preparation without standardization, as well as gaps in the information to follow up the treatment of patients resulting from the lack of records on drug administration, a condition that affects the clinical decision-making of other professionals. ${ }^{5}$ These difficulties culminate with medication errors.

At the international and national levels, errors related to the medication process are listed among the most common causes of adverse events and thus they affect the safety of hospitalized patients. $^{8-15}$ The extent of harm as well as social and financial losses still require detailed studies to measure the impact on health services in order to propose strategies to prevent and plan improvements.

The report of the US Institute of Medicine showed that drug-related errors result in about 7,000 deaths in hospitals annually and more than 10,000 deaths in outpatient settings. The study predicted that every patient admitted to a hospital would suffer at least 1.4 medication errors during their hospitalization, and every 1,000 prescriptions performed by physicians would result in 4.7 errors. ${ }^{8}$ Moreover, a Canadian study showed that one in seven patients hospitalized in clinical units experienced at least one adverse event related to nursing care with medication administration errors being among the most common. ${ }^{9}$

The main causes of errors during drug preparation involve distractions, the inappropriate layout of work areas and information that is outdated or difficult to access to perform the task. ${ }^{16,17}$ Regarding medication administration errors, mistakes in the preparation stage are the most recurrent, ${ }^{16,18,19}$ with the most common being inadequate dilution of the drug. ${ }^{20}$

Despite progress towards improved patient safety, evidence 15 years after the publication of the initial report that triggered these discussions shows that patients still suffer harm that could have been avoided; the necessary improvements in the health system have evolved on a limited scale, a condition that still characterizes patient safety as an important public health problem. ${ }^{21}$

In view of the complex situation and high probability of failures, there is an evident need to reorganize the medication process to provide safe conditions in patient care. It is understood that the medication process covers the prescription, dispensing, preparation and administration of medications and considers a series of interrelated decisions and actions involving different health professionals. ${ }^{6}$ Taking these considerations into account, the present study focuses on the phases of drug preparation and administration, with the objectives of analyzing the current situation and applying a method based on Lean thinking to establish priorities for the problems identified in order to plan improvements.

\section{METHOD}

This exploratory descriptive case study is part of a research project entitled Management Processes in Healthcare Operations in a Hospital. Participants included 13 healthcare professionals involved in the medication process of a 45-bed surgical unit of a general public university hospital in the southern region of Brazil. The inclusion criteria consisted of being a professional on the staff that performs activities related to the flow of the medication system, to have an interest in discussing this theme and availability to participate in data collection. The exclusion criterion was to have a fixed-term employment contract due to the subsequent stages of the research.

Data were collected between January and August 2015 by participant observation and through two FGs. Observation of the medication preparation and administration process was carried out over 15 hours, which was considered sufficient time to follow the value stream of medications, contemplating the professionals involved, the physical structure and the resources employed. Observations were made during the day shift due to institutional characteristics and dynamics, such as identification of the peak medication schedule, availability of medical prescriptions and 
timing of medications. The result of the observations served to elaborate a Value Stream Map (VSM) and to organize the guiding themes discussed with the professionals participating in the next stage organized based on the FG Technique. ${ }^{5}$

Two weekly FGs were coordinated by two nurses of the research team with a duration of 2 hours and 30 minutes each. The FG meetings were held in a hospital room reserved for this purpose that was easily accessible to the participants. In the first, staff involved in the process of preparing and administering medications were discussed in particular the requirements or needs of each of them to develop their work or be attended to in what they need, the current situation of these stages of the medication process, and problems present in the process in line with unmet requirements. The discussion about the problems raised continued in the second FG with the identification and application of criteria to prioritize problems in order to plan improvements.

The criterion for defining the number of FG meetings was dependent on the evolution of the group discussions, in a way that allowed the stage of prioritizing problems to be reached, thereby achieving the objective of the research. ${ }^{22}$ There were variations in the participants in the meetings of the two FGs due to the organization of work shifts. Research using focal groups (FGs) differ in the number of participants, ranging from six to 15 depending on the subject, scope and specificity of the topic being studied. ${ }^{22,23}$

No audio recording was made of the meetings; records were written down in a field diary (observations and FG) by the research team and organized using the Microsoft Visio 2013 software, which generated a graphic representation of the VSM process.

The analysis of the information followed a Lean production technique that supports efforts to improve processes, which in the context of the health area involves patient care and concentrates on the effectiveness of the result in meeting the requirements and efficiency of the flow in question. ${ }^{24}$ Hence, the analysis was focused on activities that add value or cause losses during drug preparation and administration.

In the perspective of Lean thought, activities that add value are those that meet the requirements of the client with low costs and in a timely manner. ${ }^{24}$ Losses, considered waste in the value and process chain, are activities that do not add value and are commonly classified into eight types: failures (time spent doing something incorrectly, inspecting errors or fixing errors); excess production (production before demand arises); transportation of inputs and patients; waiting for workers, resources or patients related to the imbalance of workload; unnecessary stock, focusing on the causes (can pass expiration date); movement (time spent by professionals to move around looking for inputs, arranging materials); unnecessary processes that do not add value to the patient (operations that exist due to inadequate process designs); and wasted talent or human potential (employees who are disengaged, who do not feel they are heard, do not participate in suggestions for improvements, or employees with the potential to perform tasks that require specific knowledge or skills but who perform something that does not require their knowledge). ${ }^{2}$

Field observation data and FGs were analyzed in an integrated manner following the steps defined in the VSM method: (i) identification of the clients involved in the process and their requirements; (ii) validation of the map prepared by the research team; (iii) identification of present problems based on unmet requirements; (iv) prioritization of the problems raised. ${ }^{4}$

Prioritization of the problems was defined by the researchers, applying three criteria: impact on patient safety with delayed preparation and administration of medication, implementation of short-term improvements ( 3 to 6 months) and absence of another problem prior to implement the improvement (precedence "zero"). The criteria were applied successively, that is, the first criterion was applied to each problem allocating a score of 1,3 or 9 depending on whether the relationship of the problem with the criterion was weak, intermediate or strong, respectively. Next, the second criterion was applied only to the problems that had scored 9 and then the last criterion was applied to the problems that remained. The final setting of priorities was validated in the FG.

This research complied with Resolution 466/2012 of the National Ethics Council of Research in Human Beings and obtained a favorable opinion no 14-0712 of the Ethics Research Committee of the institution (CAAE: 33705014.8.0000.5327). All participants signed free and informed consent forms for the observations and FGs.

\section{RESULTS}

The results comprised identification of the clients of the process and their requirements, mapping of the value stream of the current state of drug preparation and administration, identification of 45 problems related to the process based on unmet requirements of the customers, and prioritization of problems to plan improvements, which emerged from observation and discussions in the FGs.

With the analysis of the flow of the medications, the patients and their families, the society and the environment, nurses and nursing technicians were identified as process clients, the recipients of the services. Physicians and pharmacists were considered suppliers to the process, since they are responsible for information that triggers the activity.

The following is a list of the requirements identified for each group of clients, which correspond to mandatory items to be included for the proper functioning of the flow, both from the perspective of performing the work, and from the perspective of having needs met in respect to drug therapy. Chart 1 shows the relationship between the requirements of the nursing team (nurses and nursing technicians). 
Chart 1. Requirements of the nursing team. Porto Alegre, RS, Brazil, 2015

\begin{tabular}{|ll|}
\hline Nursing Team Requirements \\
\hline 1 & $\begin{array}{l}\text { Subjective and objective information of the patient's health collected by the multiprofessional team updated in the } \\
\text { patient's chart }\end{array}$ \\
2 & Chain of help to clarify doubts regarding the preparation and administration of medicines \\
3 & $\begin{array}{l}\text { Current and individualized medical prescriptions focused on the needs of the patient, with clear and complete } \\
\text { information for the preparation and correct administration of the medication, including infusion time }\end{array}$ \\
4 & $\begin{array}{l}\text { Time of administration of medications taking into account drug interactions and the time needed to accomplish all the } \\
\text { care demands }\end{array}$ \\
5 & $\begin{array}{l}\text { Safe preparation and disposal structure, which allows attention and focus to interpret the prescription, free of noise } \\
\text { and excessive movement of people, without interruptions }\end{array}$ \\
6 & Access to the drug and materials required for the preparation and administration of medications \\
7 & Proper functioning of the automated medication dispenser \\
8 & Easy-to-interpret institutional routines for the preparation and administration of medications \\
9 & Functional system of records for administration, drug effects and reactions \\
\hline
\end{tabular}

The requirements of the patient and his family regarding drug treatment, covered interpersonal and technical aspects. One of the requirements identified was the humanized and empathic approach by professionals, highlighted by the way the nursing staff establishes contact with the patient at the bedside through verbal identification, wearing a uniform and badge, with a smile and in a good mood. Regarding the technical aspects, it was identified that speed and resolution in the attendance of their needs add value to the patient.

Other requirements appear at the time of drug administration, such as attaining information about drug treatment, on what medication is being administered, and what the expected result is. In addition, administering the medication according to the norms was shown to be a requirement. This included the same volume at different times and days of treatment, with control of the infusion rate proceeded by the recommended washing of equipment, complying with the scheduled time of administration and correct bedside care techniques such as hand hygiene and care in the management of the venous access to avoid further punctures and infections.

As regards to environmental and social requirements, these refer to the structural conditions necessary for the preparation and administration of medications and the return that this process can offer to society. The need of a physical area in the hospital sector appropriate for the storage of medicines and supplies, including controlled temperature, was identified. The physical area must also have adequate conditions for the preparation of the drug and disposal of waste, besides the equipment necessary for storage, preparation, transport of the medicine to the patient, administration of the medicine and recording in the patient's chart. Altruism in resource use, focused on patient needs and the prevention of adverse events, was considered a requirement of society.
Figure 1 shows the VSM of the current state of the medication process, demonstrating how the flow of activities and information occurs. The continuous lines represent information in the physical environment and the squiggly lines represent electronic information via the computer system. The problems identified in the process are listed from 1 to 45 .

The process begins with the evaluation of the patient by health professionals, a step called Patient - Subjective and objective health information, which are recorded in an electronic medical record. This information serves as a basis for the preparation of the 24-hour Prescription and for Prescription Changes, which are activities of medical professionals.

The stage of Prescription Scheduling, consisting of defining the schedules when the drugs should be administered, is performed by a nursing technician. This activity demands knowledge about drug interactions and time of infusion, etc. The Preparation of the Medications is carried out by seven or eight nursing technicians in the day shift and six in the night shift with, on average, each nursing technician assuming the full care of six patients. This step occurs at the nursing station and comprises substeps including placing the drug in the automated medication dispenser, filling in labels, arranging supplies, preparing medications, arranging the drug trolley and disposing of waste.

The preparation of the drugs demands the interpretation of the prescription and involves a great deal of specific information about the preparation and disposal of waste. As an example, several drugs to be administered are reconstituted, diluted, fractionated or crushed by the nursing technician, and there are institutional routines for each route of administration. The written routines are available for consultation in an internal institutional computer system. This stage causes the team to move around, even going to the pharmacy when the necessary medications are missing. 
Figure 1. Value stream map of the current state of the medication process. Porto Alegre, RS, Brazil, 2015.

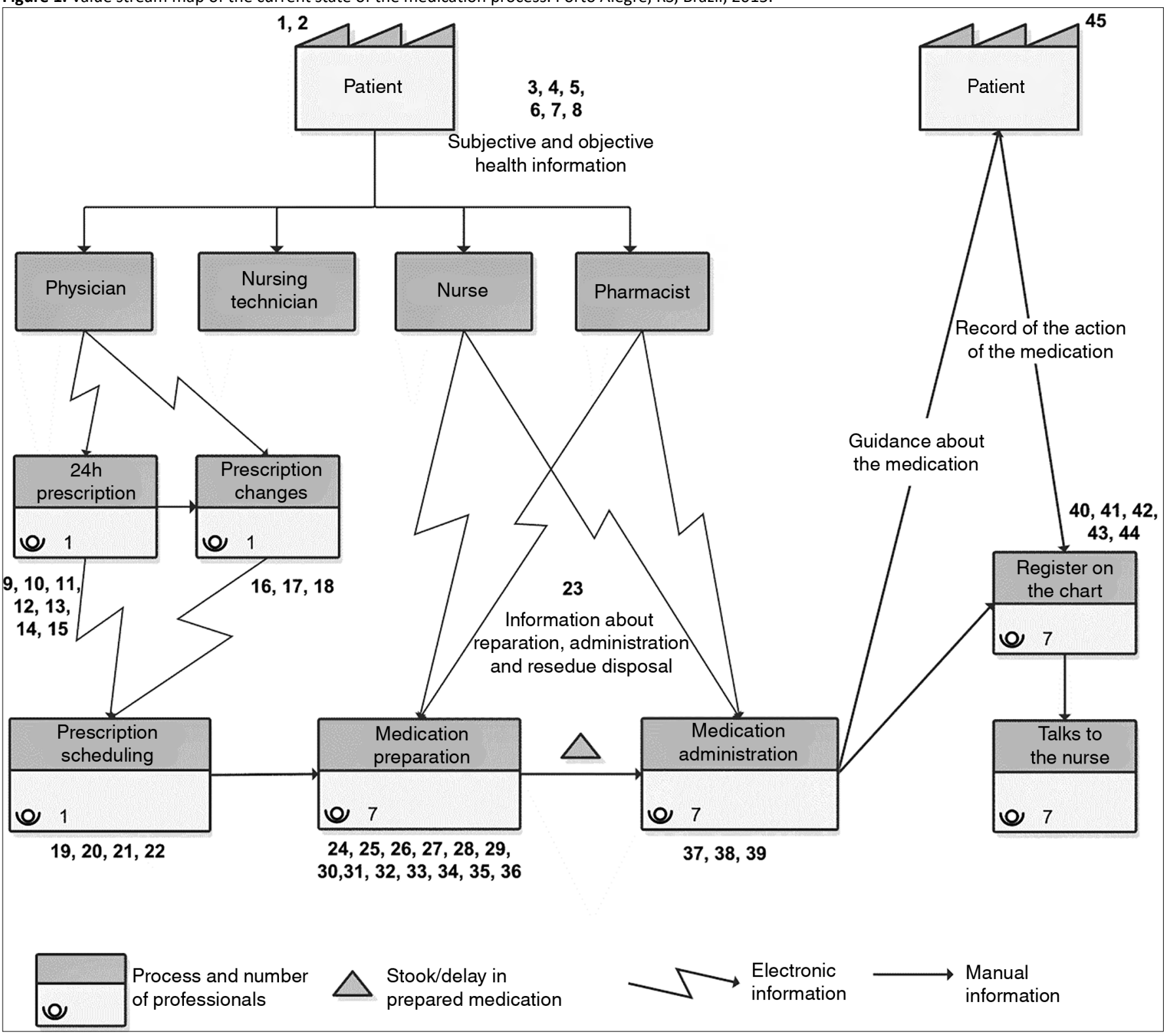

The next step in the flow is Drug Administration, which is mapped into substeps that include going to the patient, hand hygiene at the bedside, checking the patient's identification, administering the drug and disposing of waste. It should be noted that it is at this moment of direct contact with the patient that their needs and those of their family are fulfilled in relation to medical treatment, by which it is expected to meet the requirements described above. At the end of the VSM, information on patient guidance about the medicine being received is highlighted, as well as the search for information on the drug's effect. At the end of this stage, the nurse technician proceeds to Register the Information on the Patient's Chart and Talks to the Nurse about the patient's observed and reported reactions.
The steps in the drug preparation and administration process and the 45 problems identified and ordered in the VSM are presented in Chart 2.

Chart 3 lists the eight problems resulting from the application of the defined criteria for problem prioritization. The application of the first criterion to the 45 problems resulted in 20 problems with score 9 . The application of the second criterion to these 20 problems resulted in nine problems to which the third criterion was applied. Eight prioritized problems remained whose sum of the scores was 27 points, denoting a strong correlation of the problem with the three adopted criteria. 
Chart 2. Problems identified in the value stream map of the medication. Porto Alegre, RS, Brazil, 2015

\begin{tabular}{|c|c|}
\hline Process step & Problem description \\
\hline \multirow[t]{2}{*}{ The entire medication process } & $\begin{array}{l}\text { 1. Detection and referral to solve failures in the process are the responsibility of } \\
\text { the nurse or nursing technician }\end{array}$ \\
\hline & 2. There is a lack of clarity in the chain of help to solve doubts \\
\hline \multirow{6}{*}{$\begin{array}{l}\text { Patient/Subjective and objective health } \\
\text { information }\end{array}$} & 3. Shift handover time is reduced, making communications difficult \\
\hline & 4. Lack of privacy on the ward to collect information \\
\hline & 5. Language barrier to obtain information (idioms) \\
\hline & 6. Pain evaluation for patients with chronic analgesic use \\
\hline & 7. Data collection about allergies is not standardized \\
\hline & 8. Patient contact time is reduced \\
\hline \multirow{7}{*}{ 24-hour prescription } & 9. Patients without current prescriptions lead to delays in the medication process \\
\hline & 10. Lack of preparation and administration guidelines \\
\hline & 11. Lack of parameters on the prescription \\
\hline & 12. Different presentations for the same patient \\
\hline & 13. Conciliation, preparation and administration generate delay \\
\hline & 14. Routine installation of total parenteral nutrition solution is at night \\
\hline & 15. Divergence from internal protocols generates doubts \\
\hline \multirow{3}{*}{ Change of prescription } & 16. Lack of communication of changes between doctor and nurse \\
\hline & 17. Excluded drugs are not returned \\
\hline & $\begin{array}{l}\text { 18. Non-medical teams change prescription of nutritional support, with no } \\
\text { change of the computerized medical prescription }\end{array}$ \\
\hline \multirow{4}{*}{ Medical prescription scheduling } & 19. Lack of knowledge about interactions \\
\hline & 20. Rework on reprinting, updating and organizing the last prescription \\
\hline & $\begin{array}{l}\text { 21. Not shown on the patient list making it necessary to access the prescription } \\
\text { of each patient to check the completion of the task }\end{array}$ \\
\hline & 22. Item not scheduled, not flagged and not administered. \\
\hline $\begin{array}{l}\text { Information about the preparation, } \\
\text { administration and disposal of residuals }\end{array}$ & $\begin{array}{l}\text { 23. Routines are up-to-date and care staff are unaware, require interpretation } \\
\text { and calculations, and the routine consultation system is difficult to access. }\end{array}$ \\
\hline \multirow{6}{*}{$\begin{array}{l}\text { Preparation of medication/Release of } \\
\text { medication by automated medication } \\
\text { dispenser }\end{array}$} & 24. The released medicine is not identified immediately \\
\hline & $\begin{array}{l}\text { 25. Bar code reader is difficult to handle with ineffective reading delaying the } \\
\text { process }\end{array}$ \\
\hline & 26. Existence of expired medicine in the automated medication dispenser \\
\hline & $\begin{array}{l}\text { 27. Lack of ergonomic organization of drugs by volume of use, validity, } \\
\text { appearance or similar name }\end{array}$ \\
\hline & 28. Short login time, generates need to re-input user and password again \\
\hline & 29. Failure to replace saline solution as it is not required to register use \\
\hline $\begin{array}{l}\text { Preparation of the drug/Search for the } \\
\text { drug in the pharmacy }\end{array}$ & $\begin{array}{l}\text { 30. Nursing technician needs to go away from the station to the dispensing } \\
\text { pharmacy in search of medicines that are not in the automated medication } \\
\text { dispenser }\end{array}$ \\
\hline
\end{tabular}




\begin{tabular}{|ll|}
\hline Process step & Problem description \\
\hline 31. Storage environment without temperature and humidity control \\
32. Excessive movement of the team because of the distribution of materials and \\
for waste disposal from the nursing station \\
33. Interruptions in preparation environment does not allow concentration \\
34. Preparation of the medicines for several patients causes delays \\
35. Manual filling of medication identification labels \\
36. Tray dividers do not allow proper organization. Trolley used for both \\
medication and bathing \\
37. The patient's own medication administration is not supervised by the team \\
38. Delayed administration in relation to the scheduled time \\
39. Checking is a visual identification of drug and patient \\
40. Not done in real time. Manual check in two places \\
41. Lack of computer availability \\
42. Check is carried out at scheduled time and not at time of administration \\
43. Information reported by the patient of the drug's action is not recorded in \\
real time causing delay in clinical decision making \\
44. Adverse reactions to drugs are rarely registered during evolution, causing \\
difficulty for the pharmacist to trace them \\
45. Drugs are not received at the scheduled time due to delays in the process.
\end{tabular}

Chart 3. Prioritized issues in the value stream map of the medication. Porto Alegre, RS, Brazil, 2015

\begin{tabular}{|c|c|}
\hline Process step & Problem description \\
\hline The entire medication process & 2. There is a lack of clarity in the chain of help to solve doubts \\
\hline \multirow[b]{2}{*}{ Prescription } & $\begin{array}{l}\text { 9. Patients without current prescriptions lead to delays in the medication process and } \\
\text { the need to reorganize care activities and the pharmacy work process }\end{array}$ \\
\hline & $\begin{array}{l}\text { 11. Lack of parameters on the prescription, refers to the relationship between dosage } \\
\text { and the patient's clinical parameters, as well as to the permanence of drugs that the } \\
\text { patient does not use on the prescription. }\end{array}$ \\
\hline \multirow{2}{*}{$\begin{array}{l}\text { Preparation of medication/Release } \\
\text { of medication by automated } \\
\text { medication dispenser }\end{array}$} & $\begin{array}{l}\text { 24. The released medicine is not immediately identified with the patient's data, failing } \\
\text { to comply with the regulations for the safe use of medicines. }\end{array}$ \\
\hline & $\begin{array}{l}\text { 27. Lack of ergonomic organization of drugs by volume of use, validity, appearance or } \\
\text { similar name }\end{array}$ \\
\hline \multirow[t]{2}{*}{ Preparation of the drug } & $\begin{array}{l}\text { 32. Excessive movement of the team because of the distribution of materials and for } \\
\text { disposal of waste }\end{array}$ \\
\hline & 33. Interruptions in the preparation environment does not allow concentration \\
\hline Recorded on patient chart & $\begin{array}{l}\text { 41. Lack of availability of computers for care activities such as scheduling, printing } \\
\text { prescriptions, care records, medication effects after administration and the clinical } \\
\text { evolution of the patient }\end{array}$ \\
\hline
\end{tabular}




\section{DISCUSSION}

Studies show that the principles of Lean production have potential applications in health services, especially in hospital environments, allowing the development of plans for improvements that encompass quality and safety, as well as efficiency and effectiveness, considering the factors that characterize this sector as complex. ${ }^{24,25}$

In relation to customer requirements, these are described as needs to be satisfied to provide a service or receive a quality product defined from the customer's perspective, which indicate them as fundamental factors to be considered in the characteristics of quality. ${ }^{3}$ The analysis of customer requirements that are affected by the problems identified in the VSM supports the motivation to establish an improvement plan capable of transforming the current situation of the process. ${ }^{4}$

The trigger in the preparation and administration of medications is the most recent medical prescription. Medical prescriptions are an instrument of communication between health professionals; therefore, they must be the most recent, and be consulted and checked at each drug preparation, which reflects the effective collaboration of human resources in the equity of care and humanization. ${ }^{26}$

Environmental safety was considered in the structure required to prepare the medication in order to allow focused attention to interpret the prescription, free from noise and excessive circulation of people and without interruption. It is reported in the literature that medication errors may be related to failure to interpret prescriptions ${ }^{7}$ and lack of attention at the time of drug preparation and administration induced by interruptions. ${ }^{20}$ Other environmental factors are associated with drug preparation errors, such as insufficient or irregular lighting, high or frequent changes in noise levels, interruptions, lack of space, no place to wash the hands, presence of dirt, humidity or waste, and lack of organization of the nursing station. ${ }^{17,26}$

From a patient's perspective, considering the requirements of speed and resolution to meet their needs with the correct administration of medications, all the identified problems are directly related to these expectations. The results of the present study corroborate the requirements of patients and their families as described in the Prescription Safety Protocol, Use and Administration of Medicines highlighted as the seven norms that should to be followed: patient, medication, route, correct time and dose, correct registration and correct indication. ${ }^{6}$

Recently, the adoption of nine good practices for the preparation, administration and monitoring of medicines has been recommended, divulging guidelines that, in addition to the seven already mentioned, include the need for patient guidance and recognition of the right of refusal. ${ }^{27}$ In the present study, the need for patient guidance was identified as a requirement to be met at the time of drug administration, described by the patient's need to know what they are receiving and what the expected result is.

Regarding the lack of parameters for prescribed drugs, which may exclude individualization or focus on needs, the reference document of the National Patient Safety Program highlights the importance of defining the condition that determines the use or the interruption of use of the prescribed medication. ${ }^{28}$ For society and the environment, prescribing drugs without purpose can generate patient insecurity and waste.

From the presented data, it is understood that the adoption of the lean thinking framework and the participation of the nursing team allowed a broad and detailed analysis of the medication process. The use of the tools proposed in this approach demonstrated the diversity and complexity of this process, giving visibility to the central role of the nursing team in identifying problems, as well as in planning improvements.

Practical implications of the present study were translated into initiatives focusing on the prioritized problems, supported by the management of the institution. Modifications were made in the medical prescription to standardize the validity schedules and guide the indication of medications and in the organization of automated medication dispensers in order to optimize the ergonomic arrangement of medications. The project addressing the safety of the environment of medication preparation and administration is being developed.

Limitations of this study included the fact that the scope of the value stream mapping was restricted to the stages of drug preparation and administration, although this delimitation is supported by the complexity and the significance of these steps.

\section{CONCLUSION}

The main premise for conducting this study was the respect to the people involved in the process, considering the intention to analyze the process as it occurs remembering that the solutions to improve performance depend on these people.

The use of the value stream mapping tool from a Lean perspective, systematically and objectively provided elements to identify activities that add value or cause losses in the preparation and administration of drugs, with a view to effectively improve the medication process. The involvement of the team in the prioritization of the problems enabled the professionals to rethink the work process and to seek alternatives for the planning of future improvements in a systematized way thereby adding value to the process.

Through the results, the need to reduce the waste of time, resources and work of the nursing team is considered urgent in order to improve the quality and safety of the medication process, thereby treating patients effectively and providing what they need to achieve higher levels satisfaction. 


\section{REFERENCES}

1. Toussaint J, Gerard RA. Uma transformação na saúde: como reduzir custos e oferecer um atendimento inovador. Porto Alegre: Bookman; 2012.

2. Graban M. Hospitais Lean: melhorando a qualidade, a segurança dos pacientes e o envolvimento dos funcionários. Porto Alegre: Bookman; 2012.

3. Joint Commission Resources. O pensamento lean na saúde: menos desperdício filas e mais qualidade e segurança para o paciente. Porto Alegre: Bookman; 2013.

4. Worth J, Shuker T, Keyte B, Ohaus K, Luckman J, Verble D, et al. Aperfeiçoando a jornada do paciente: melhorando a segurança do paciente, a qualidade e a satisfação enquanto desenvolvemos habilidades para resolver problemas. São Paulo: Lean Institute Brasil; 2013.

5. Magalhães AMM, Moura GMSS, Pasin SS, Funcke LB, Pardal BM, Kreling A. The medication process, workload and patient safety in inpatient units. Rev Esc Enferm USP [Internet]. 2015 Dec; [cited 2016 Jul 2]; 49(no.spe):43-50. Available from: http://www.scielo.br/scielo. php?pid=S0080-62342015000700043\&script=sci_arttext\&tlng=en

6. Ministério da Saúde (BR). Protocolo de Segurança na Prescrição, Uso e Administração de Medicamentos. Brasília (DF): Ministério da Saúde; 2013.

7. Gimenes FRE, Marques TC, Teixeira TCA, Mota MLS, Silva AEBC, Cassiani SHB. Medication wrong-route administrations in relation to medical prescriptions. Rev Latino Am Enferm [Internet]. 2011 Jan/Feb; [cited 2016 Jun 10]; 19(1):11-7. Available from: http://www.scielo.br/pdf/ rlae/v19n1/03.pdf

8. Kohn LT, Corrigan JM, Donaldson MS. Institute of Medicine. To Err is Human: Building a Safer Health System. Washington: National Academy Press; 2000.

9. D'Amour D, Dubois C, Tchouaket E, Clarke S, Blais R. The occurrence of adverse events potentially attributable to nursing care in medical units: cross sectional record review. Int J Nurs Stud [Internet]. 2014 Jun; [cited 2016 Mar 20]; 51(6):882-91. Available from: http://dx.doi.org/10.1016/j. ijnurstu.2013.10.017

10. Keers RN, Williams SD, Cooke J, Ashcroft DM. Prevalence and nature of medication administration errors in health care settings: a systematic review of direct observational evidence. Ann Pharmacother [Internet]. 2013 Feb;47(2):237-56. DOI: 10.1345/aph.1R147

11. EMA. Medication-errors workshop. Tackling medication errors: European Medicines Agency workshop calls for coordinated EU approach. London: European Medicines Agency (EMA). 2013. Available from: http://www. ema.europa.eu/docs/en_GB/document_library/Press_release/2013/03/ WC500139570.pdf

12. Ferreira PC, Dantas ALM, Diniz KD, Ribeiro KRB, Machado RC, Tourinho FSV. Evento adverso versus erro de medicação: percepções da equipe de enfermagem atuante em terapia intensiva. J Res Fundam Care Online [Internet]. 2014 Apr/Jun;6(2):725-34. Available from: http://www. seer.unirio.br/index.php/cuidadofundamental/article/viewFile/3088/ pdf_1281. DOI: 10.9789/2175-5361.2014v6n2p725

13. Paranaguá TTB, Bezerra ALQ, Santos ALM, Silva AEBC. Prevalência e fatores associados aos incidentes relacionados à medicação em pacientes cirúrgicos. Rev Esc Enferm USP [Internet]. 2014 Feb;48(1):418. Available from: http://www.scielo.br/scielo.php?pid=S008062342014000100041\&script=sci_arttext\&tlng=pt. DOI: $10.1590 /$ S0080-623420140000100005

14. Leite B, Mistro S, Carvalho C, Mehta SR, Badaro R. Cohort study for evaluation of dose omission without justification in a teaching general hospital in Bahia, Brazil. Int J Qual Health Care [Internet].
2016 Jun;28(3):288-93. Available from: https://www.ncbi.nlm.nih.gov/ pubmed/?term=Cohort+study+for+evaluation+of+dose+omission+wit hout+justification+in+a+teaching+general+hospital+in+Bahia\%2C+B razil. DOI: 10.1093/intqhc/mzw016

15. Oliveira RM, Leitão IMTA, Silva LMS, Figueiredo SV, Sampaio RL, Gondim MM. Estratégias para promover segurança do paciente: da identificação dos riscos às práticas baseadas em evidências. Rev Enferm Esc Anna Nery [Internet]. 2014 Jan/Mar;18(1):122-9. Available from: http://www.scielo.br/pdf/ean/v18n1/en_1414-8145ean-18-01-0122.pdf. DOI: 10.5935/1414-8145.20140018

16. Veloso IR, Telles Filho PCP, Durão AMS. Identificação e análise de erros no preparo de medicamentos em uma unidade pediátrica hospitalar. Rev Gaúcha Enferm (Online) [Internet]. 2011 Mar; [cited 2016 Mar 20] 32(1):93-9. Available from: http://www.scielo.br/scielo.php?script=sci_ar ttext\&pid=S1983-14472011000100012

17. Gimenes FRE, Marck PB, Atila EG, Cassiani SHB. Engaging nurses to strengthen medication safety: fostering and capturing change with restorative photographic methods: a restorative approach. Int J Nurs Pract [Internet]. 2015 Dec; [cited 2016 Mar 20]; 21(6):741-8. Available from: http://onlinelibrary.wiley.com/doi/10.1111/ijn.12304/full

18. Silva AEBC, Reis AMM, Miasso Al, Santos JO, Cassiani SHB. Adverse drug events in a sentinel hospital in the State of Goiás, Brazil. Rev Latino Am Enferm [Internet]. 2011 Mar/Apr; [cited 2016 Jun 19]; 19(2):378-86 Available from: http://www.scielo.br/pdf/rlae/v19n2/21.pdf

19. Silva LD, Camerini FG. Analisys of intravenous medication administration in sentinel network hospital. Texto Contexto Enferm [Internet]. $2012 \mathrm{Jul} /$ Sep; [cited 2016 Mar 20];21(3):633-41. Available from: http://www.scielo. br/pdf/tce/v21n3/en_v21n3a19.pdf

20. Abreu CCF, Rodrigues MA, Paixão MPBA. Erros de medicação reportados pelos enfermeiros da prática clínica. Rev Enferm Ref [Internet]. $2013 \mathrm{Jul}$ [cited 2016 Mar 3]; III(10):63-8. DOI: http://dx.doi.org/10.12707/RIII1301

21. National Patient Safety Foundation. Livre de danos: Acelerar a melhoria da segurança do paciente quinze anos depois de To Err Is Human. Boston: National Patient Safety Foundation; 2015.

22. Busanello J, Lunardi Filho WD, Kerber NPC, Santos SSC, Lunardi VL, Pohlmann FC. Grupo focal como técnica de coleta de dados. Cogitare Enferm [Internet]. 2013 Abr/Jun;18(2):358-64. DOI: http://dx.doi. org/10.5380/ce.v18i2.32586

23. Sehenen GD, Alves CN, Wilhelm LA, Resse LB. Utilização do grupo focal como técnica de coleta de dados em pesquisa: relato de experiência. Ciênc Cuid Saúde [Internet]. 2015 Abr/Jun;14(2):1194-200. Available from: http://periodicos.uem.br/ojs/index.php/CiencCuidSaude/article/ view/21960. DOI: 10.4025/cienccuidsaude.v14i2.21960

24. Buzzi D, Plytiuk C. Pensamento enxuto e sistemas de saúde: um estudo da aplicabilidade de conceitos e ferramentas Lean em contexto hospitalar. Rev Qual Emergente [Internet]. 2011; [cited 2016 Jul 2] 2(2):18-38. Available from: http://dx.doi.org/10.5380/rqe.v2i2.25187

25. D'Andreamatteo A, lanni L, Lega F, Sargiacomo M. Lean in healthcare: A comprehensive review. Health Policy [Internet]. 2015 Sep; [cited 2016 Jul 2];119(9):1197-209. Available from: https://www.ncbi.nlm.nih.gov/ pubmed/25737260. DOI: 10.1016/j.healthpol.2015.02.002

26. Teixeira TC, Cassiani HB. Root cause analysis of falling accidents and medication errors in hospital. Acta Paul Enferm [Internet]. $2014 \mathrm{Mar} / \mathrm{Apr}$ [cited 2016 Jul 2]; 27(2):100-7. Available from: http://www.scielo.br/scielo.php?pid=S0103-21002014000200003\&script=sci_arttext\&tlng=en

27. Conselho Regional de Enfermagem de São Paulo (SP). Uso seguro de medicamentos: guia para preparo, administração e monitoramento. São Paulo: COREN; 2017.

28. Ministério da Saúde (BR). Fundação Oswaldo Cruz. Agência Nacional de Vigilância Sanitária. Documento de referência para o Programa Naciona de Segurança do Paciente. Brasília (DF): Ministério da Saúde; 2014. 